\title{
O LUGAR DA TEORIA NO ENSINO DE LITERATURA: UMA REFLEXÃO SOBRE AS ESPECIFICIDADES DA LITERATURA E AS ESCOLHAS DOS PROFESSORES
}

Érica Cristina dos Santos Marta Passos Pinheiro

\section{RESUMO}

Neste artigo, apresentamos uma reflexão sobre as especificidades da literatura e as escolhas literárias dos professores. Partimos do pressuposto de que a dificuldade de definir literatura influencia tanto a seleção de textos realizada pelos professores quanto à forma como os textos são trabalhados.

PALAVRAS-CHAVE: teoria da literatura; práticas docentes; escolhas literárias.

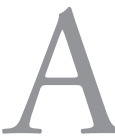

escola é a instituição responsável pela alfabetização dos indivíduos e é a ela que "a sociedade delega a responsabilidade de prover as novas geraçóes das habilidades, conhecimentos, crenças, valores e atitudes considerados essenciais à formaçáo de todo e qualquer cidadão." ${ }^{1}$ Dentre essas habilidades, destacam-se as relacionadas à formaçáo de leitores. Contudo, é preciso definir o seguinte: leitores de quê??2

1 SOARES, Magda. Letramento: um tema em três gêneros. 2.ed. Belo Horizonte: Autêntica, 2001a, p. 84.

2 Soares chama a atenção para a necessidade de se dar complemento ao verbo ler: "quando se diz que o brasileiro lê pouco ou lê mal, o que se está entendendo por ler? Lê pouco o quê? Lê mal o quê??" (SOARES, Magda. Ler, verbo intransitivo. In PAIVA, Aparecida et. al., (Org.) Leituras literárias: discursos transitivos. Belo Horizonte: CEALE/Autêntica, 2005, p. 30). 
Em se tratando da leitura de texto literário, é importante refletirmos, segundo Paulino, sobre suas especificidades, sem deixarmos de levar em conta o que há de comum (as semelhanças) entre essa leitura e a de textos não literários, já que, numa perspectiva contemporânea, "todos os domínios discursivos, sem exceção, exigiriam e desenvolveriam habilidades complexas e competências sociais de seus leitores."3

A dificuldade de muitos professores com o ensino de literatura talvez venha da própria dificuldade de definição do objeto com o qual se trabalha. Afinal, existem especificidades particulares ao texto literário? É possível definir literatura? Neste artigo, nos propomos a apresentar uma reflexão sobre essas questôes, dialogando com teóricos da literatura de algumas correntes e épocas. Sem apresentar receitas sobre o que o professor deve fazer, pretendemos contribuir para sua prática, a partir de reflexões teóricas sobre as especificidades da literatura, seu processo de canonização e as escolhas de obras literárias realizadas pelos professores. Partimos do pressuposto de que a dificuldade de definir literatura influencia tanto a seleção de textos realizada pelos professores quanto a forma como os textos são trabalhados. Sendo assim, reconhecemos que a simples transmissão de conhecimentos teóricos não modifica a prática docente, mas que reflexões teóricas são fundamentais para a melhoria dessa prática.

\section{(In) definindo literatura}

A aporia da definição do termo "literatura" resulta em assertivas que, por mais simplistas que possam parecer - "Literatura é aquilo que se ensina e ponto final" ou "Literatura é literatura" análise de características que possam ser atribuídas exclusivamente aos textos

3 PAULINO, Graça. Algumas especificidades da leitura literária. In PAIVA, Aparecida et. al., (Org.) Leituras literárias: discursos transitivos. Belo Horizonte: CEALE/Autêntica, 2005, p. 61.

4 BARTHES apud COMPAGNON, Antoine. O demônio da teoria: literatura e senso comum. Tradução de Cleonice Paes Barreto Mourão e Consuelo Fortes Santiago. Belo Horizonte: Ed. UFMG, 1999, p. 30.

5 COMPAGNON, Antoine. O demônio da teoria: literatura e senso comum. Tradução de Cleonice Paes Barreto Mourão e Consuelo Fortes Santiago. Belo Horizonte: Ed. UFMG, 1999 , p. 30. 
literários e que os diferenciem dos não literários, de exclusão de possibilidades, de tentativas de responder a questóes que abrangem a função e a natureza da literatura.

Barthes ${ }^{6}$ sustenta que a literatura se configura como um uso da linguagem que está à margem das relaçôes de poder: a linguagem literária, para ser compreendida, não necessita, ao contrário da linguagem cotidiana, seguir os padrôes linguísticos nem obedecer estritamente às normas estruturais. Assim, o escritor utiliza livremente a estrutura linguística e, sendo a norma, a gramática, uma forma de poder institucionalizado, transgredi-la é uma maneira de não se submeter ao poder. Portanto, a literatura constitui um importante instrumento de transgressão. Também Candido $(2006)^{7}$ corrobora a visão de literatura como forma de arte que permite uma "estilização formal". Lajolo compartilha com Candido a contraposição da linguagem literária à linguagem cotidiana. Como não há nenhuma estrutura cujo uso seja restrito aos textos literários, o que pode distinguir um texto como sendo literário é o arranjo que se faz dessas estruturas, somado a outras condiçóes definidas por Lajolo, como o escape ao "imediatismo, à predictibilidade e ao estereótipo das situaçóes e usos da linguagem que configuram a vida cotidiana." que instaura a natureza literária de um texto é a relação que as palavras estabelecem com o contexto, com a situação de produção e leitura."

O que se convencionou chamar de literatura pode ser observado, no mundo ocidental economicamente desenvolvido, a partir de meados do século XVIII. Nesses países, "o aumento do número de alfabetizados e uma maior concentração urbana" 10 levaram a um relevante aumento do número de leitores. A prática da leitura, ou pelo menos o domínio dessa capacidade, deixou de distinguir a elite letrada da massa leitora. Como destaca Abreu:

6 BARTHES apud COMPAGNON, Antoine. O demônio da teoria: literatura e senso comum. Tradução de Cleonice Paes Barreto Mourão e Consuelo Fortes Santiago. Belo Horizonte: Ed. UFMG, 1999.

7 CANDIDO, Antonio. Literatura e Sociedade: estudo de história e teoria literária. 9 ed. Rio de Janeiro: Ouro sobre Azul, 2006.

8 LAJOLO, Marisa. O que é literatura. 11 ed. São Paulo: Brasiliense, 1989, p. 23.

9 LAJOLO, Marisa. O que é literatura. 11 ed. São Paulo: Brasiliense, 1989, p. 38.

10 ABREU, Márcia. Letras, belas-letras, boas letras. In: BOLOGNINI, Carmen Zink (Org.). História da Literatura: o discurso fundador. Campinas, São Paulo: Mercado de Letras, Associação de Leitura do Brasil (ALB). São Paulo: Fapesp, 2003, p. 16. 
A definiçấo moderna de literatura se fez no momento em que entraram em cena novos leitores, novos gêneros, novos escritores e novas formas de ler. Escritores e leitores eruditos interessavamse fortemente em diferenciar-se de escritores e leitores comuns a fim de assegurar seu prestígio intelectual, abalado pela disseminação da leitura. Isso os levou a eleger alguns autores, alguns gêneros e algumas maneiras de ler como os melhores. Convencionaram chamar a isso de literatura. ${ }^{11}$

Como podemos observar, a definição moderna de literatura veio acompanhada de um processo de canonização dos textos: um determinado grupo de obras e autores foi selecionado como representante do que se convencionou chamar de literatura. O fundamento ideológico da nacionalidade foi um importante orientador desse processo seletivo, e estratégias eram concebidas "para que o contato com esses escritos fosse garantia de distinção social." 12

A formação das identidades nacionais veio acompanhada pela escritura das histórias literárias. Coube à História da Literatura, à qual muitos intelectuais do século XIX se dedicaram, selecionar, hierarquizar e organizar cronologicamente os textos, estabelecendo relaçóes estreitas entre Literatura e História. Fruto dessa estreita relação foi a ênfase dada à biografia dos autores, que costumava orientar a leitura de suas obras (as famosas interpretaçôes "vida e obra").

No oitocentos brasileiro, durante o Romantismo - como ocorreu no século XVIII em países europeus -, o fundamento ideológico da nacionalidade foi um importante orientador do processo realizado pela História da Literatura de seleção, hierarquização e organização de obras e autores, de canonização da literatura brasileira. No nosso Romantismo, a literatura contribuiu para a construção de uma identidade nacional, buscando definir nossas origens (nos romances indianistas), resgatando (inventando) um pouco de nossa história, definindo, nos romances urbanos e crônicas - textos que apresentavam carac-

11 ABREU, Márcia. Letras, belas-letras, boas letras. In: BOLOGNINI, Carmen Zink (Org.). História da Literatura: o discurso fundador. Campinas, São Paulo: Mercado de Letras, Associação de Leitura do Brasil (ALB). São Paulo: Fapesp, 2003, p. 28.

12 ABREU, Márcia. Letras, belas-letras, boas letras. In: BOLOGNINI, Carmen Zink (Org.). História da Literatura: o discurso fundador. Campinas, São Paulo: Mercado de Letras, Associação de Leitura do Brasil (ALB). São Paulo: Fapesp, 2003, p. 47. 
terísticas desse gênero cuja consolidação data do final do século XIX -, hábitos e costumes de nossa sociedade, inventando tradiçóes.

O Brasil nação foi construído discursivamente através da união de várias áreas de conhecimento, como a História, a Geografia, a Literatura e o Jornalismo, que começava a ascender. Em nosso Romantismo, enquanto a História definia o Brasil no tempo, passado e presente, projetando um futuro, a Geografia definia o Brasil no espaço, e a Literatura aproximava essas definiçôes da realidade dos leitores, utilizando sua característica de ficção, de criaçáo, apresentando, assim, uma urgente utilidade ${ }^{13}$. Como ocorreu no século XVIII em países europeus, a nacionalização, como fundamento ideológico, foi um importante orientador do processo de canonização de nossa literatura.

Certo é que, como assegura Compagnon ${ }^{14}$, a definição de literatura oscila conforme a cultura e a época. Culler afirma, sobre a tentativa de definição do termo: "Na maior parte do tempo, o que leva os leitores a tratar algo como literatura é que eles a encontram num contexto que a identifica como literatura: num livro de poemas ou numa seção de uma revista, biblioteca ou livraria." ${ }^{15}$ Nessa afirmação de Culler, ressalta-se a junção de dois elementos essenciais aos estudos sobre literatura: o leitor e o contexto. Esses dois, somados ao autor e à estrutura do texto, constituem o objeto de que se ocupam as teorias literárias. Porém, nem sempre o leitor e o contexto constituíram elementos importantes na análise literária. Durante muito tempo, a importância, ou a essência do texto literário, residia, acreditava-se, no próprio texto ou nas intençốes do autor.

13 Afinal, como observa Rouanet: "Por mais completo e bem delineado que fosse o quadro (definido pela História e Geografia), haveria sempre o risco de que o espectador, a quem ele se destinava, permanecesse 'estrangeiro' diante do que ali se representava." (Aquarelas de um Brasil in História, Ciência, Saúde-Manguinhos, v.I, no 1. Rio de Janeiro: Casa de Rui Barbosa, 1994, p. 103.). Daí o importante papel da literatura, que deveria, através do discurso ficcional, contribuir para a identificação do leitor com a "realidade" que estava sendo construída. Sobre a fundação de uma literatura nacional, consultar ROUANET, Maria Helena. Eternamente em Berço Esplêndido: a fundação de uma literatura nacional. São Paulo: Siciliano, 1991.

14 COMPAGNON, Antoine. O demônio da teoria: literatura e senso comum. Tradução de Cleonice Paes Barreto Mourão e Consuelo Fortes Santiago. Belo Horizonte: Ed. UFMG, 1999.

15 CULLER, Jonathan. Teoria literária: uma introdução. Tradução de Sandra Vasconcelos. Sáo Paulo: Beca Produçóes Culturais Ltda. 1999, p. 34. 
Sob essa última perspectiva, a Crítica Fenomenológica - que influenciou tanto o formalismo russo quanto as teorias da recepção - tenta isolar a obra literária de suas condiçôes de produção e dos efeitos de leitura, reduzindo o texto a uma materialização da consciência do autor. Todas as partes componentes do texto são o resultado de uma essência unificadora: a mente do autor ${ }^{16}$. Ao identificar, no texto, a repetição constante de padrôes, esses críticos supunham alcançar as estruturas profundas da mente do autor. Entretanto, para a fenomenologia, as informaçóes biográficas não têm valor. O que importa é o que vem à superfície a partir da análise objetiva e desinteressada - no sentido de destituída de valores pessoais - do texto. Para Eagleton, "trata-se, em outras palavras, de um modo de análise totalmente acrítica, destituída de avaliaçóes. (...) é uma simples recepção passiva do texto." 17 Apesar disso, pode-se dizer que a Fenomenologia influenciou o surgimento das teorias da recepção (que serão discutidas mais adiante) por valorizar o papel do leitor, uma vez que este é o responsável por fazer emergir esses aspectos da consciência do autor através do percurso do texto ${ }^{18}$.

O Formalismo Russo, que floresceu na segunda década do século XX, propunha uma análise formal, estrutural do texto literário e considerava a literatura como uma forma particular de organização da linguagem. Constitui-se, ainda, na aplicação dos conhecimentos da linguística formal, fundada por Saussure, ao estudo dos textos literários, enfatizando a materialidade dos mesmos, excluindo, assim, a importância da figura do autor ${ }^{19}$. Roman Jakobson, linguista e crítico literário, considerado o fundador do Formalismo, criticava as teorias literárias em vigor até então. Para ele, as teorias englobavam qualquer estudo que pretendesse se referir à literatura, sem necessariamente definir claramente seu objeto de estudo:

16 EAGLETON, Terry. Teoria da literatura: uma introdução. Tradução de Waltensir Dutra. 6 ed. São Paulo: Marins Fontes, 2006.

17 EAGLETON, Terry. Teoria da literatura: uma introdução. Tradução de Waltensir Dutra. 6 ed. São Paulo: Marins Fontes, 2006, p. 91.

18 CULLER, Jonathan. Teoria literária: uma introdução. Tradução de Sandra Vasconcelos. São Paulo: Beca Produçóes Culturais Ltda. 1999.

19 EAGLETON, Terry. Teoria da literatura: uma introdução. Tradução de Waltensir Dutra. 6 ed. São Paulo: Marins Fontes, 2006; COMPAGNON, Antoine. O demônio da teoria: literatura e senso comum. Tradução de Cleonice Paes Barreto Mourão e Consuelo Fortes Santiago. Belo Horizonte: Ed. UFMG, 1999. 
Até hoje, os historiadores da literatura, o mais das vezes, assemelhavam-se à polícia que, desejando prender determinada pessoa, tivesse apanhado, por via das dúvidas, tudo e todos que estivessem num apartamento, e também os que passassem casualmente na rua naquele instante. Tudo servia para os historiadores da literatura: os costumes, a psicologia, a política, a filosofia. Em lugar de um estudo da literatura, criava-se um conglomerado de disciplinas mal-acabadas. Parecia-se esquecer que estes elementos pertencem às ciências correspondentes: História da Filosofia, História da Cultura, Psicologia, etc., e que estas últimas podiam, naturalmente, utilizar também os monumentos literários como documentos defeituosos e de segunda ordem. Se o estudo da literatura quer tornar-se uma ciência, ele deve reconhecer o 'processo' como seu único 'herói' ${ }^{20}$.

Os formalistas - sem a pretensão de definir o termo literatura, mas tentando dissociar o texto literário do não literário - chamaram de literariedade o traço distintivo que confere ao texto um caráter literário. Mas em que consistia essa literariedade? Para eles, a linguagem literária se distanciava da linguagem comum, cotidiana, e esse desvio provocaria no leitor uma certa desfamiliarização, ou um certo estranhamento. Assim, o que torna o texto literário, além dos componentes artísticos formais, é a capacidade de provocar esse estranhamento no leitor. Entretanto, como atestam estudos posteriores, não há estruturas que sejam empregadas somente no texto literário, e nem todo desvio linguístico - que seria uma característica distintiva dos textos literários - pode ser considerado poético ${ }^{21}$.

$\mathrm{Na}$ análise literária formalista - que enfatizava a poesia, apesar de estender seus conceitos ao estudo da prosa -, o autor não constituía objeto de interesse, uma vez que o texto era considerado apenas uma organização

${ }^{20}$ JAKOBSON, Roman. Aspectos linguísticos da tradução. In: JAKOBSON, Roman. Linguistica e comunicação. Tradução de Izidoro Blikstein e José Paulo Paes. São Paulo: Editora Cultrix, 1969, p. 95-97.

21 EAGLETON, Terry. Teoria da literatura: uma introdução. Tradução de Waltensir Dutra. 6 ed. São Paulo: Marins Fontes, 2006; LAJOLO, Marisa. O que é literatura. 11 ed. São Paulo: Brasiliense, 1989. 
específica da linguagem, não sendo adequado analisá-lo como a expressão do pensamento do autor ${ }^{22}$. Também o leitor era relegado, uma vez que o texto constituía uma estrutura autossuficiente. Assim, a teoria formalista defende a imanência do texto literário, que não tem finalidade prática imediata, como um bilhete ou um texto didático, e que independe do contexto de produção. Embora possa parecer que as correntes formalistas sejam reducionistas, elas foram fundamentais para os estudos literários porque trouxeram o texto para o centro da discussão, que até então se baseava no binômio vida/obra de autores.

Também o New Criticism, concentrando-se preponderantemente na análise de poemas, dissociou o texto de seu autor e de seu público alvo, privilegiando uma leitura intrínseca, imanentista, formal do texto, buscando nele os elementos responsáveis por desencadear a emoção do leitor, sem, contudo, se ocupar dos efeitos provocados no leitor - tarefa que, na época, caberia à psicologia. Essa corrente desvincula ainda a obra de seu contexto de produçáo. Além disso, não cabe ao leitor, ao contrário do que propunha a fenomenologia, tentar desvendar as motivaçóes do autor nem os traços de personalidade do mesmo presentes no texto. O que importava nessa análise eram as palavras dispostas sobre a página, uma vez que as intençôes do autor, ainda que pudessem ser reconstituídas, não influíam na interpretação do texto.

Em oposição à crítica fenomenológica, surge o Estruturalismo, uma vertente da análise formal que floresceu na década de 1960 e que tenta aplicar ao texto literário os processos de análise da linguística estrutural, tendo constituído a proposta de maior prestígio nas universidades ${ }^{23}$. Não mais buscando a literariedade do texto, o objetivo era identificar as estruturas presentes que tornavam possível a experiência literária, sem a finalidade de analisá-la. Propondo uma análise fria da literatura, sem levar em consideração o contexto de produção ou o valor atribuído à obra, os estruturalistas chocaram o mundo ao reduzir a obra literária a um construto e abordá-la clinicamente. "Com o advento do estruturalismo, o mundo dos grandes estetas e dos eruditos humanistas literários da Europa do século XX parecia ter terminado." 24

22 EAGLETON, Terry. Teoria da literatura: uma introdução. Tradução de Waltensir Dutra. 6 ed. São Paulo: Marins Fontes, 2006.

23 ZILBERMAN, Regina. Estética da recepção e história da literatura. Sáo Paulo: Ática, 2009.

24 EAGLETON, Terry. Teoria da literatura: uma introdução. Tradução de Waltensir Dutra. 6 
Já o contexto de produção da obra literária foi preocupação da Crítica Marxista, a qual propõe uma leitura extrínseca do texto. Importavam, nessa proposta, os aspectos sociais, políticos e econômicos da época de produção da obra, ao passo que o estudo biográfico do autor deveria ser preterido, enfatizando a visão da luta de classes na análise dos acontecimentos ficcionais. A crítica literária marxista buscava compreender a relação entre a literatura e a produção econômica de uma época.

Essas são apenas algumas das inúmeras proposições teóricas acerca da análise literária. Como se pode notar, os protagonistas dessas teorias já oscilaram entre a obra em si e o autor, sendo que, durante muito tempo, reinou uma prática de ensino centrada apenas neste último elemento. Estudar determinada obra literária incluía estudar a biografia de seu autor. Caberia ao leitor, então, tão somente a tarefa de descobrir o sentido único que o texto apresentava. Segundo os estudos de Eco (A obra aberta, 1962) ${ }^{25}$ e de Barthes (A morte do autor, 1968) ${ }^{26}$, o autor deixa de ser, em meados da década de 1960, a figura central do texto, detentor desse significado único, e o leitor passa a assumir um papel decisivo, de desbravador do texto, de suas possibilidades de interpretação, através da leitura. Para Barthes, uma vez contado um fato, o autor entra na sua própria morte. A figura do autor se dilui na interação entre leitor e obra. Apesar disso, muitos livros e manuais didáticos ainda centram o estudo das obras literárias na figura do autor e muitos professores perpetuam essa tendência. A literatura, porém, não pode ser definida apenas pelas características imanentes do texto ou pelas intençôes e habilidades de quem a produziu. Outros fatores como a cultura, a sociedade e o mercado são definidores desse objeto.

O procedimento de leitura especificamente e, consequentemente, a ênfase no leitor, só passou a ser o centro da teoria literária a partir de 1960, com a Estética da Recepção, fundada por Jauss e seus colegas da Escola de Constança, que propunha um retorno ao estudo da história e da historicidade da literatura, destacando o leitor como principal agente do processo literário.

ed. São Paulo: Marins Fontes, 2006, p. 160.

25 ECO, Umberto. A obra aberta. 8 ed. São Paulo: Perspectiva, 1991.

26 BARTHES, Roland. A morte do autor. In: O Rumor da Língua. São Paulo: Martins Fontes, 2004. 
Sob essa perspectiva, o texto deve ser analisado considerando-se a recepção da obra na época de seu contexto de produção em comparação à recepção no momento atual de leitura, processo ao qual Jauss dá o nome de atualização. Para isso, o leitor evoca, no ato da leitura, todo o seu conhecimento prévio, seu repertório de experiências sociais e de códigos em vigor, seu horizonte de expectativas. Para Jauss, "a finalidade e efeito alcançado pela arte, que libera seu destinatário das percepçóes usuais e confere-lhe nova visão da realidade" 27 é a emancipação do leitor:

em primeiro lugar, [a experiência estética] liberta o ser humano dos constrangimentos e da rotina cotidiana; estabelece uma distância entre ele e a realidade convertida em espetáculo; pode preceder a experiência, implicando então a incorporação de novas normas, fundamentais para a atuação na e compreensão da vida prática; e, enfim, é concomitantemente antecipação utópica, quando projeta vivências futuras, e reconhecimento retrospectivo, ao preservar o passado e permitir a redescoberta de acontecimentos enterrados ${ }^{28}$.

De certa maneira, Jauss enfatiza o caráter formador da arte e da literatura: esta predetermina a concepção de mundo do leitor, ao contrariar suas expectativas e renovar sua percepção de mundo. Segundo Zilberman,

Nenhum leitor fica imune às obras que consome; essas, da sua parte, não são indiferentes às leituras que desencadeiam. Portanto, para Jauss, o leitor constitui um fator ativo que interfere no processo como a literatura circula na sociedade. Só que a ação do leitor não é individualista; nem cada leitor age de modo absolutamente singular. Segundo Jauss, as épocas ou as sociedades constituem horizontes de expectativa dentro dos quais as obras se situam. Essas expectativas advêm da

27 ZILBERMAN, Regina. Estética da recepção e história da literatura. São Paulo: Ática, 2009, p. 49.

28 ZILBERMAN, Regina. Estética da recepção e história da literatura. São Paulo: Ática, 2009, p. 54 . 
“compreensão prévia do gênero, da forma e da temática das obras anteriormente conhecidas e da oposição entre linguagem poética e linguagem prática." 29

O leitor, visto sob essa perspectiva, não só deixa de ter um papel passivo de mero receptor da obra como passa a atualizá-la no ato de leitura. Assim, como defende Compagnon ${ }^{30}$, tanto o leitor, com suas experiências, conhecimentos e vivências, modifica a leitura da obra quanto a obra modifica as atitudes e valores do leitor. Para Eagleton, "quando a obra passa de um contexto histórico para outro, novos significados podem ser dela extraídos ${ }^{31}$ ", através da intersecção dos horizontes de expectativa do leitor com aquele pré-definido pela obra, no momento da leitura. Assim, também a obra deixa de ser vista como guardiã de um sentido único, estático, e passa a assumir um caráter dinâmico em função das inúmeras leituras que suscita.

A Estética da Recepçáo, portanto, visa a analisar as diversas interpretaçôes possíveis de uma obra pelo leitor, a partir das várias possibilidades de composição de sentido promovidas pelos textos. Vários teóricos da recepção, como Eco, Culler, Ingarden e Iser, defendem que o texto precisa ser preenchido pelo leitor no ato de leitura; porém, isso se dá dentro de certos limites impostos pelo próprio texto. Fish considera que os limites da interpretação são, na verdade, determinados pela comunidade interpretativa em que o leitor se insere. Dentro dessa perspectiva, o que explica o fato de vários leitores produzirem um mesmo sentido para uma obra é que esses leitores pertencem a comunidades interpretativas, determinadas por valores sociais semelhantes. Para eles, portanto, o sentido não é algo predeterminado pelo autor, mas um efeito alcançado pelo leitor.

$\mathrm{Na}$ atualidade, o leitor e os mediadores da leitura são o centro das discussôes, já que é impossível, no trabalho com textos literários, dissociar a lei-

29 ZILBERMAN, Regina. Estética da recepção e história da literatura. São Paulo: Ática, 2009, p. 5.

30 COMPAGNON, Antoine. O demônio da teoria: literatura e senso comum. Tradução de Cleonice Paes Barreto Mourão e Consuelo Fortes Santiago. Belo Horizonte: Ed. UFMG, 1999.

31 EAGLETON, Terry. Teoria da literatura: uma introdução. Tradução de Waltensir Dutra. 6 ed. São Paulo: Marins Fontes, 2006, p. 98. 
tura do papel do leitor, que é parte do processo de leitura e de construção de sentidos, e não uma entidade que recebe passivamente o conteúdo lido. Sobre a relaçâo do leitor com a leitura de literatura, um conceito fundamental é o de pacto ficcional proposto por Eco ${ }^{32}$. Não é raro encontrarmos alunos que acreditam que todo texto - incluindo-se o literário - é fruto de observaçóes reais, de acontecimentos reais e, portanto, deve ser lido como sendo um relato do real. Segundo Eco,

A norma básica para se lidar com uma obra de ficção é a seguinte: o leitor precisa aceitar tacitamente um acordo ficcional (...). O leitor tem de saber que o que está sendo narrado é uma história imaginária, mas nem por isso deve pensar que o escritor está contando mentiras. De acordo com John Searle, o autor simplesmente finge dizer a verdade. Aceitamos o acordo ficcional e fingimos que o que é narrado aconteceu ${ }^{33}$.

Dessa forma, o ponto de partida do leitor diante de uma obra literária deve ser o pacto ficcional: o leitor deve ter ciência de estar diante de uma obra de ficção. É necessário que o leitor "finja” que aquilo aconteceu. Cabe ao professor, como mediador das leituras na escola, salientar esse aspecto concernente à leitura de obras literárias.

Na obra Seis passeios pelos bosques da fiç̧ão ${ }^{34}$, em que o bosque é uma metáfora para os textos narrativos e para os caminhos percorridos pelo leitor no processo de leitura, Eco destaca o papel do leitor na obra literária. Segundo ele, o texto precisa, a todo momento, ser "preenchido" pelo leitor. Assim, o leitor parece ser previsto pelo autor, como se fosse parte essencial da narrativa, o que ele denomina "leitor-modelo". Eco afirma que há várias nomenclaturas para o papel do leitor no texto ${ }^{35}$, mas que elas nem sempre significam a mesma

32 ECO, Umberto. Seis passeios pelos bosques da ficção. Trad. Hildegard Feist. São Paulo: Companhia das Letras, 2009.

33 ECO, Umberto. Seis passeios pelos bosques da ficção. Trad. Hildegard Feist. São Paulo: Companhia das Letras, 2009, p. 81.

34 ECO, Umberto. Seis passeios pelos bosques da fição. Trad. Hildegard Feist. São Paulo: Companhia das Letras, 2009.

35 Segundo Eco (2009), "No amplo leque das obras sobre a teoria da narrativa, sobre a estética da recepção e sobre a crítica orientada para o leitor, existem várias entidades chamadas 
coisa. Ele nomeia o leitor de duas formas: leitor-modelo e leitor empírico. Este último, para Eco, seria o leitor real, "de carne e osso"; o primeiro seria aquele que o autor tem em mente ao produzir a obra. O papel do leitor-modelo seria o de se guiar pelas pistas deixadas pelo autor-modelo ${ }^{36}$ ao longo da narrativa. Essa perspectiva é reiterada na obra Interpretação e superinterpretação: "Como a intenção do texto é basicamente a de produzir um leitor-modelo capaz de fazer conjeturas sobre ele, a iniciativa do leitor-modelo consiste em imaginar um autor-modelo que não é empírico e que, no fim, coincide com a intenção do texto." ${ }^{37}$ Estrutura semelhante - denominada de "leitor implícito" - é prevista por Iser ${ }^{38}$, para quem o leitor é responsável por fazer o texto revelar as múltiplas interpretaçóes possíveis. Segundo Iser,

o leitor implícito não tem existência real; pois ele materializa o conjunto das preorientaçóes que um texto ficcional oferece, como condiçôes de recepção a seus leitores possíveis. Em consequência, o leitor implícito não se funda em um substrato empírico, mas sim na estrutura do texto. (...) a concepção do leitor implícito designa então uma estrutura do texto que antecipa a presença do receptor ${ }^{39}$.

Assim, o leitor implícito, teoricamente, serve de referência ao leitor empírico para, no ato da leitura, considerar a função estabelecida por essa estrutura textual e não apenas seus conhecimentos prévios. Ambas as categorias (leitor

Leitores Ideais, Leitores Implícitos, Leitores Virtuais, Metaleitores, e assim por diante (...). Nem sempre esses termos são sinônimos." (ECO, 2009, p. 22-23).

36 O autor-modelo é uma voz que "se manifesta como uma estratégia narrativa, um conjunto de instruções que nos são dadas passo a passo e que devemos seguir quando decidimos agir como leitor-modelo." (ECO, 2009, p. 21). Assim, e somente sob essa perspectiva, fazem sentido questōes do tipo "o que o autor quis dizer?", uma vez que cabe ao leitor-modelo entender as pistas deixadas pelo autor-modelo para se chegar à interpretaçáo pretendida por este último.

37 ECO, Umberto. Interpretação e superinterpretação. Trad. MF. São Paulo: Martins Fontes, 1993 , p. 75.

38 ISER, Wolfgang. $O$ ato da leitura: uma teoria do efeito estético. Tradução Johannes Kretschmer. São Paulo: Ed.34, 1996, v. 1, p. 73.

39 ISER, Wolfgang. $O$ ato da leitura: uma teoria do efeito estético. Tradução Johannes Kretschmer. São Paulo: Ed.34, 1996, v. 1, p. 73. 
implícito e leitor-modelo), portanto, constituem estruturas textuais previstas pelo autor. Segundo Iser, “o conceito de leitor implícito é, portanto, uma estrutura textual prevendo a presença de um receptor, sem necessariamente defini-lo" 40 e a categoria prevista por Eco se configura como o "sustentáculo de sua [do texto] estratégia de interpretação." ${ }^{41}$

Como se depreende, as teorias da recepção criaram várias categorias de leitores, mas essas se mostram frágeis, já que não atingem o leitor real, que é imprevisível. Apesar disso, elas foram fundamentais para o deslocamento do eixo de interesses/interpretaçóes: do texto para o leitor, ou ainda, para o processo dialógico entre eles. Além disso, como salienta Guidio,

A experiência estética, orientada para o receptor, póe em xeque o modo como foi construída a noção de cânone literário, que, até então, parecia impossível de ser colocada sob suspeita. Jauss afirma que nenhuma obra é clássica em si, pois somente pode ser compreendida ou, esteticamente falando, fruída, a partir do jogo de perguntas e respostas proporcionado no decorrer das leituras. No processo dialógico entre texto e leitor, cabe considerar as leituras precedentes e atuais, visto que as diferentes recepçóes contribuem para a atualização das obras; para tanto, um estudo meramente positivista não mais deve ter espaço ${ }^{42}$.

Sendo assim, podemos afirmar que o cânone literário não é único, definitivo. Considerando que as diferentes recepçóes contribuem para a atualização das obras, o cânone incorpora escritores do passado que vão sendo revalorizados, e também deixa de lado escritores que já foram bem considerados, como é o caso, no Brasil, de Coelho Neto. Podemos citar ainda a redescoberta,

40 Apud ECO, Umberto. Seis passeios pelos bosques da ficção. Trad. Hildegard Feist. São Paulo: Companhia das Letras, 2009, p. 22.

41 ECO, Umberto. Seis passeios pelos bosques da ficção. Trad. Hildegard Feist. São Paulo: Companhia das Letras, 2009, p. 22.

42 GUIDIO, Milena Magalhães. Reflexões sobre a posição do leitor nas teorias da recepção, p. 6. Disponível em: http://www.albertolinscaldas.unir.br/posicaodoleitor.htm, 10 de agosto de 2012 . 
pela poesia de vanguarda brasileira, de Sousândrade, poeta contemporâneo dos românticos, ignorado até então pela historiografia literária.

Observa-se que o ensino de literatura atualmente, pelo menos no plano teórico, é influenciado pelas teorias da recepção: o leitor tem papel ativo no processo de leitura. Chiappini chama a atenção para esse papel: "O texto é um trabalho da linguagem (...). Se entendermos o texto 'não como uma coisa, fato ou dado', mas como reflexão sobre a experiência e experiência da reflexão, teremos de reconhecer que, enquanto leitores, participamos desse trabalho.” ${ }^{33}$ Do outro lado está o papel do professor, que tem por objetivo, entre outros, desenvolver nos alunos as habilidades de leitura. Segundo a autora, o professor deve

colocar-se criticamente em relação à leitura proposta pelo livro didático ou pela história literária, como uma leitura possível. Em decorrência dessa atitude nova, respeitaremos a leitura alheia - especialmente a dos alunos - e saberemos explorar a riqueza da tensão criada pelas várias perspectivas em jogo, que passarão a dançar na sala de aula e em nossas cabeças ${ }^{44}$.

No contexto escolar, encontra-se uma prática bastante diferente da proposta acima: não raro o aluno é instigado pelo professor a encontrar no texto aquilo "que o autor quis dizer". Muitos alunos carecem ser alforriados no processo de leitura, ou seja, precisam que o professor os liberte da tarefa de tentar descobrir um sentido único no texto literário e os proclame senhores de suas leituras.

\section{Seleção de obras: "leitores de quê"?}

É necessário retomarmos a pergunta colocada no início deste trabalho: na escola, pretende-se formar "leitores de quê"? Quais são os textos que vêm sendo propostos para leitura nessa importante comunidade interpretativa formadora de leitores? Segundo Cosson, entre os professores,

43 CHIAPPINI, Ligia. Reinvenção da catedral: língua, literatura, comunicação, novas tecnologias e políticas de ensino. São Paulo: Cortez, 2005, p. 139.

44 CHIAPPINI, Ligia. Reinvenção da catedral: língua, literatura, comunicação, novas tecnologias e políticas de ensino. São Paulo: Cortez, 2005, p. 141. 
há aqueles que sequer admitem discussão e continuam a afirmar a essencialidade do cânone e da tradição. (...) Herdeiros e guardiães da tradição, eles consideram que o desconhecimento de uma obra canônica é a falha maior em uma formação literária. Há outros que, assediados pelas editoras, adotam como leitura apenas os últimos lançamentos, liberados que estão da obrigação de ler o cânone $e^{45}$.

Esses dois extremos apontados por Cosson nos levam a alguns questionamentos: o professor que trabalha apenas com o cânone sente-se à vontade para selecionar, entre obras da literatura contemporânea, bons textos para seus alunos? Essa seleção "elitista" poderia estar associada a uma insegurança do professor em relação às especificidades, à natureza, à função, aos valores da literatura? Por outro lado, o professor que seleciona apenas obras contemporâneas, geralmente best-sellers juvenis, não apresenta, de certa forma, as mesmas dificuldades do primeiro? Vale ainda destacar que, na era dos temas transversais propostos pelos Parâmetros Curriculares Nacionais (1997) ${ }^{46}$ - ética, pluralidade cultural, meio ambiente, saúde, orientação sexual - , corre-se o risco de que esses temas sobreponham-se sobre quaisquer definiçóes ou critérios de valores literários. Textos não literários sobre os temas priorizados, que apresentam alguma construção ficcional, são selecionados como literários. Por outro lado, textos literários, que abordam os tais temas, são trabalhados de forma pragmática, utilitária, desrespeitando-se sua natureza. Esses temas estão de acordo com o discurso do "politicamente correto" que, como destaca Vianna, vem influenciando a formação de cânones desde a década de 1990 e pode ser observado no interior das universidades.

$\mathrm{Na}$ era do "politicamente correto" o risco é que ele se sobreponha de maneira tão avassaladora que passe a ser

45 COSSON, Rildo. Entre o cânone e o mercado: a indicação de textos na escola. In: PAULINO, Graça e COSSON, Rildo (Org.) Leitura literária: a mediação escolar. Belo Horizonte: Faculdade de Letras da UFMG, 2004, p. 94.

46 BRASIL. Secretaria de Educação Fundamental. Parâmetros curriculares nacionais: introdução aos parâmetros curriculares nacionais / Secretaria de Educação Fundamental. - Brasília: MEC/SEF, 1997. 
o único critério adotado, sem que o próprio texto seja sequer considerado. Ilustrativo desta informação são os cânones formados em universidades americanas, sob a vigília de certos grupos representativos de minorias, que, como numa propaganda que não se quer racista, tenta salpicar um pouco de tudo. $O$ resultado não é, infelizmente, a possibilidade de entrada de escritores de nações periféricas ou pertencentes a minorias nos cânones formados por grandes centros. O critério é mais uma vez o da exemplificação, sendo que aqui não são escolhidos exemplos, mas exemplares. Entáo, a presença de um negro, de um índio, de uma mulher negra ou índia, de um gay, serve apenas para simular que a nova ordem mundial é hoje bem mais tolerante ${ }^{47}$.

Portanto, "não se trata (de nada adianta) de destruir os cânones, mas fazer deles uma leitura não-canônica." ${ }^{48} \mathrm{O}$ questionamento do elemento político, ou seja, uma análise dos interesses a que esse elemento atende, faz parte dessa leitura. É importante considerar que os parâmetros que elegeram determinado grupo de obras e autores, em um determinado momento histórico, estão de acordo com uma determinada ideologia, não se mantendo os mesmos ao longo do tempo. A valorização de minorias, destacada acima por Vianna, ocorreu na área de ciências humanas como um todo, sob a influência dos Estudos Culturais. De acordo com Escosteguy:

Os Estudos Culturais preocuparam-se, em primeira mão, com os produtos da cultura popular e dos mass media que expressavam os rumos da cultura contemporânea. Com a extensão do significado de cultura - de textos e representaçóes práticas vividas -, considera-se em foco toda produção de sentido. (...) o que se pode dizer é que não existe um confronto

47 VIANNA, Thereza Christina Vicente. Cânone e literatura menor. In $Q f w f q$, vol. 2, no 1. Rio de Janeiro: universidade do Estado do Rio de Janeiro, 1996, p. 26.

48 VIANNA, Thereza Christina Vicente. Cânone e literatura menor. In $Q f w f q$, vol. 2, no 1. Rio de Janeiro: universidade do Estado do Rio de Janeiro, 1996, p. 26. 
bipolar e rígido entre as diferentes culturas. Na prática, o que acontece é um sutil jogo de intercâmbios entre elas. (...) Em determinados momentos, a cultura popular resiste e impugna a cultura hegemônica; em outros, reproduz a concepção de mundo e de vida das classes hegemônicas ${ }^{49}$.

Os Estudos Culturais não restringem seu objeto de estudo aos gêneros considerados elevados e ressaltam as relaçóes entre texto e sociedade, as configuraçóes de certos aspectos da vida social no texto literário. Bordini apresenta da seguinte forma o viés dos Estudos Culturais:

A valorização das manifestaçôes populares, a investigação dos processos materiais de formação do público leitor, a defesa ao direito de acesso aos bens da alta cultura pelos grupos minoritários, exigiam que se considerasse não apenas a literatura, mas a cultura em que esta se produzia como novo campo de discussão teórica. (...) Seja no interior das obras individuais, seja entre elas, seja no seu contorno imediato ou mais distante, interpenetram-se características, de modo que conceitos como literatura culta/literatura de massa/literatura popular, ou literatura nacional/literatura universal, ficção/nãoficção perdem sua força delimitadora ${ }^{50}$.

Para Paulino, nos estudos literários, essa valorização veio acompanhada do questionamento (e muitas vezes negação) dos cânones literários.

Os textos, produçóes culturais de linguagem, foram confundidos com a própria realidade a que se referiam, diretamente ou não. Entra em cena, com força total nos estudos literários, a dominância de alguns novos cânones

49 ESCOSTEGUY, Ana Carolina. Estudos culturais: uma introdução. In: O que é, afinal, estudos culturais? Organização e tradução de Tomaz Tadeu da Silva. 4 ed. Belo Horizonte: Autêntica Editora, 2010, passim.

50 BORDINI, Maria da Glória. Estudos culturais e estudos literários. Letras de Hoje. Porto Alegre, v. 41, n. 3, p. 11-22, set. 2006, p. 14-15. 
multiculturalistas de significação. Nesse processo, os cânones estéticos foram negados (...) Meros documentos culturais se tornaram todos os textos literários, sendo ignorados os critérios de qualidade, tanto de construção quanto de significação ${ }^{51}$.

O questionamento do cânone ocidental em nome do "politicamente correto" - valorização de textos representantes das chamadas minorias: classes, etnias, gêneros sexuais -, como ressalta Perrone-Moisés, "resultou em censuras e exclusôes nos currículos escolares." ${ }^{2}$ Essa pesquisadora, assumindo uma posição de defesa do cânone ocidental, destaca as obras que foram "expulsas" da escola:

as obras menos exemplares para essas posiçóes ideológicas (de defesa das minorias), isto é, aquelas que "não passam de obras de arte"; ou, pior, aquelas que se propóem como arte, atividade considerada pelos "culturalistas" como idealista, eurocêntrica, anacrônica e ideologicamente suspeita $^{53}$.

Entre questionamentos que negam o cânone ocidental e defesas das "virtudes literárias” desse cânone, é possível seguir uma terceira via? Paulino des-

51 PAULINO, Maria das Graças Rodrigues. Formação de leitores: a questão dos cânones literários. Revista portuguesa de educação. Vol. 17, número 1. Universidade do Minho. Braga, Portugal. 2004, p. 51. Paulino utiliza as categorizaçóes de Todorov e Genette. "Textos modelares por seus elementos coerentes e relevantes se destacam em duas modalidades: a de construção, que abrange qualidades do trabalho de linguagem, do modo de contar, e a de significação, que abrange os componentes de uma narrativa social e existencialmente relevante, capaz de ampliar as dimensóes dos mundos vividos e imaginados pelo leitor." Segundo a pesquisadora, essas duas modalidades só fazem sentido se levarmos em conta "as instâncias de recepção, o repertório textual e os horizontes de expectativas dos leitores." (JAUSS apud PAULINO, 2004, p. 50). Levando em conta essas instâncias, Paulino destaca a expressão cânones estéticos de produção e recepçáo.

52 PERRONE-MOISÉS, Leyla. O cânone dos escritores-críticos. In: Altas Literaturas. Companhia das Letras: São Paulo, 2003, p. 349.

53 PERRONE-MOISÉS, Leyla. O cânone dos escritores-críticos. In: Altas Literaturas. Companhia das Letras: São Paulo, 2003, p. 349. 
taca na investigação de Chiappini - em Invasão da catedral: literatura e ensino em debate, publicado em 1983 - a proposta de uma terceira via. Em vez de repudiar obras canônicas do ponto de vista estético ou se limitar a defendê-las, Chiappini questiona certa escolarização restritiva dos cânones literários, criticando o caráter paradoxal do autoritário tratamento escolar da literatura no Brasil.

Essa terceira via proposta por Chiappini é embasada em uma postura teórica que busca o equilíbrio entre concepçôes oriundas de dois "extremos" da teoria literária ${ }^{54}$ : de um lado o formalismo e o estruturalismo e de outro o pós-estruturalismo e suas diversas correntes teóricas. Esses dois extremos são criticados pela pesquisadora:

Enquanto formalistas e estruturalistas tinham a ilusão de poder identificar os fatores definidores da literariedade, o pósestruturalismo e suas diversas correntes teóricas póem no centro a figura do leitor e o diálogo intertextual, problematizando a autonomia da obra literária, a especificidade do discurso literário em relação ao não-literário, buscando esclarecer os processos sociais e institucionais que definem a canonização dos textos literários e excluem outros do cânone. Do pólo de concentração do texto passa-se ao diametralmente oposto, o pólo do leitor. Se os formalistas muitas vezes absolutizavam a autonomia do literário, não apenas distinguindo os discursos pela forma $\mathrm{e}$ esquecendo os fatores institucionais e sociais dessa distinção, mas também afirmando sua independência em relação à realidade e à história, os pós-estruturalistas absolutizam muitas vezes o pólo do leitor, defendendo a leitura à deriva e concebendo a produção de sentido como ato individual e até arbitrário ${ }^{55}$.

54 Para Chiappini, "as diferentes tendências da teoria literária oscilam entre duas direçôes contraditórias. De um lado, a ênfase na especificidade e na autonomia, de outro, em sua capacidade para a representação, sua representatividade. De um lado, a literariedade, de outro, a mímesis." CHIAPPINI, Ligia. Reinvenção da catedral: língua, literatura, comunicação, novas tecnologias e políticas de ensino. São Paulo: Cortez, 2005, p. 245.

55 CHIAPPINI, Ligia. Reinvenção da catedral: língua, literatura, comunicação, novas tecnologias e políticas de ensino. São Paulo: Cortez, 2005, p. 249. 
Para Chiappini, deve existir um equilíbrio entre a defesa da autonomia absoluta do texto literário e a descrença em qualquer nível de autonomia. Essa descrença está presente quando se defende a "livre produção de sentido dos leitores individuais ou de leitores socialmente ou institucionalmente localizados." 56 Buscando um "equilíbrio", a pesquisadora defende, com o respaldo teórico de Antonio Candido ${ }^{57}$, "o direito à forma”, ao destacar a literatura como arte de profunda elaboração formal, através das possibilidades que a língua oferece, e, ao mesmo tempo, descreve algumas funçóes sociais da literatura, destacando a necessidade de:

distinguir os textos que servem a um lazer produtivo e ativo daqueles que favorecem um lazer alienado, passivo; a literatura que enriquece e desafia a imaginação e a inteligência, dos produtos que as embotam na repetição e na facilidade. Se nos cegamos na luta contra o cânone, caímos num "vale-tudo" e não distinguimos esses níveis que o próprio mercado e suas agências, dentre elas as editoras, distinguem ${ }^{58}$.

O que se pode questionar, unindo-se teorias e prática docente, é o que os professores têm feito em sala de aula: valorizam somente o que é considerado como alta cultura - o cânone literário -, valorizam somente textos da literatura contemporânea não consagrados pela crítica - como muitos best-sellers voltados para o público jovem - ou propóem um trabalho com ambas as formas de cultura, cientes de seus diferentes propósitos e funçôes? Segundo Todorov

devemos encorajar a leitura de todos os meios - inclusive a dos livros que o crítico profissional considera com condescendência, se não com desprezo: não apenas romances populares levaram ao

56 CHIAPPINI, Ligia. Reinvenção da catedral: língua, literatura, comunicação, novas tecnologias e políticas de ensino. São Paulo: Cortez, 2005, p. 250.

57 CANDIDO, Antonio. O direito à literatura in CANDIDO, Antonio. Vários escritos. 4 ed. reorg. Pelo autor. Rio de Janeiro: Ouro Sobre Azul / São Paulo: Livraria Duas Cidades, 2004, p. 170.

58 CHIAPPINI, Ligia. Reinvenção da catedral: língua, literatura, comunicação, novas tecnologias e políticas de ensino. São Paulo: Cortez, 2005, p. 259. 
hábito da leitura milhôes de adolescentes, mas, sobretudo, lhes possibilitaram a construção de uma primeira imagem coerente do mundo, que, podemos nos assegurar, as leituras posteriores se encarregarão de tornar mais complexas e nuançadas ${ }^{59}$.

Partir das preferências do aluno - sugestão contida nos Parâmetros Curriculares Nacionais - pode ser uma boa estratégia de trabalho com os textos literários na escola. Dentre essas preferências, é comum a presença de best-sellers voltados para o público jovem, já que esse público vem sendo bombardeado por propagandas editoriais nas mídias. Mas é importante salientar que, entre as obras designadas como juvenis, e também infantis, encontram-se bons textos literários. Essa produção vem passando por um processo de canonizaçáo que merece ser investigado. Destaca-se que ao lado de textos caracterizados pelo fundamento ideológico da formação moral da criança e do jovem - presente na origem do próprio "gênero" literatura infantil e juvenil -, encontram-se textos reconhecidos por críticos literários que se dedicam ao estudo dessa produção. Eles defendem, para a análise do "gênero" em questão, o uso dos mesmos referenciais teóricos válidos para a análise de qualquer texto literário.

Mas, certamente, se o professor permanecer nas preferências dos jovens, ou, no Ensino Médio, nas obras voltadas para o público juvenil, não irá contribuir para o desenvolvimento do letramento literário de seus alunos. As obras canonizadas ou já reconhecidas pela crítica literária e por uma elite letrada devem ser democratizadas pela escola. É importante que se esclareça que essas obras, como quaisquer outras, dialogam com as obras de seu tempo, com as que as precederam e, no momento da leitura, com as obras do universo do leitor. Sendo assim, muito importante também é a forma como os textos literários vêm sendo trabalhados na escola, a forma como eles vêm sendo escolarizados, seja nos materiais didáticos ou nas aulas de Português e Literatura. A reflexão sobre sua natureza, suas especificidades, assim como sobre os processos de canonizaçáo de textos contribuem para uma melhor escolarização.

59 TODOROV, Tzvetan. A literatura em perigo. Tradução de Caio Meira. 3 ed. Rio de Janeiro: DIFEL, 2010, p. 82. 


\title{
THE PLACE OF THEORY IN LITERATURE TEACHING: A REFLECTION ON THE LITERATURE SPECIALTIES AND THE CHOICES MADE BY TEACHERS
}

\begin{abstract}
This paper presents a reflection on the literature specialties and on the literary choices made by teachers. Our assumption is that the difficulty in defining literature influences the selection of texts made by teachers as well as the way teachers work the texts with their students.

KEYWORDS: Literature theory; Literature teaching practices; Literary choices.
\end{abstract}

Recebido em: 04/06/2012

Aprovado em: 25/01/2013 